\title{
Análisis de la calidad de los menús del Programa de Alimentación Escolar Nacional en una ciudad de Río de Janeiro - Brasil
}

\author{
Quality analysis of menus of the \\ National School Feeding Program in a city \\ of Rio de Janeiro State - Brazil
}

\begin{abstract}
The aim of this study was to perform a qualitative analysis of menus planned and executed in a public school of the State of Rio de Janeiro (Brazil). During 1 month school menus were evaluated according to the Qualitative Evaluation of Menus Preparation method by using variables related to food and lunch preparation. Data in relation to the total number of days of menus were evaluated. Planned and executed menus showed, respectively, 20\% and $26.7 \%$ of presence of salad, $100 \%$ and $80 \%$ of inclusion of fruits and $0 \%$ and $26,7 \%$ of presence of sweets, respectively. Regarding the garnish, planned menus presented $50 \%$ of preparations with vegetables; however, on executed menus, this percentage was $26.7 \%$. The main differences between menus were unscheduled changes that can negatively contribute to the quality of school meals. Reformulations in the planning of menus and more control in their implementation are suggested as measures to promote healthy eating habits in the school environment.

Key words: Feeding program; qualitative analysis; school meal; child; menu planning.
\end{abstract}

Daniele da Silva Bastos Soares Roseane Moreira Sampaio Barbosa Patrícia Henriques Patrícia Camacho Dias Daniele Mendonça Ferreira

Emília de Jesus Ferreiro Nutrition School. Department of Social Nutrition. Fluminense Federal University. Niterói, Rio de Janeiro, Brazil. (1) CEP: $24020-140$

Dirigir la correspondencia a: Profesora

Daniele da Silva Bastos Soares Department of Social Nutrition. Fluminense Federal University. Emília de Jesus Ferreiro Nutrition School. Rua Mário Santos Braga $n^{\circ} 30,4^{\circ}$ andar, Valonguinho, Centro, Niterói, Rio de Janeiro, Brazil. CEP: 24020-140. Phone: + $55212629-9841$ E-mail: danielebastos@id.uff.br

Este trabajo fue recibido el 16 de Marzo de 2015 y aceptado para ser publicado el 31 de Julio de 2015.

\begin{abstract}
Nomenclatura
Food and Nutrition Security (FNS); National School Feeding Program (NSFP); Qualitative Evaluation of Menus Preparation (QEMP); Rio de Janeiro (RJ); School Food and Nutrition Unit (SFNU); Meat Accompaniment 1 (MA1); Meat Accompaniment 2 (MA2); High Fat Content (HFC); Low Fat Content (LFC); Lean sauce (LS); Fat sauce (FS); Trans fatty acids (TFA); Food Guide for the Brazilian Population (FGBP); Santa Catarina (SC); Distrito Federal (DF); Fruits and Vegetables (FV); Noncommunicable Chronic Diseases (NCD).
\end{abstract}

\section{INTRODUCTION}

In recent years, significant advances in the political field of Food and Nutrition Security (FNS) have occurred in Brazil, either in the reorientation of some policies and programs, new institutional arrangements and/or the allocation and distribution of resources. These changes appear to have produced positive effects on different dimensions of FNS; however, there are still historical challenges in the political field and others typical of developing societies that ultimately affect public policies. The obesity epidemic, the increased consumption of foods rich in salt, fat and sugar and the reduced consumption of foods such as rice, beans, fruits and vegetables, and other healthy foods, are among them (1).

The National School Feeding Program (NSFP) is the oldest and uninterrupted food and nutrition program in Brazil up to the present day and has recorded in its history, especially the last ten years, a number of regulatory changes that express the courses in the political field of FNS. This program shows some basic guidelines to ensure the FNS as the explicit support to sustainable development, articulation with family agriculture and the ban to less healthy foods (2-4). Therefore, NSFP can be considered strategy to support the promotion of FNS, affecting different dimensions of the food chain from production to consumption (5). In this sense, observation and analysis of the nutritional quality of menus planned and offered to students are of great importance because these aspects directly impact the ability to contribute or not to FNS through this program.

The Qualitative Evaluation of Menus Preparation (QEMP) is a menu management tool in the preparation of meals which assessment covers preparations, colors, preparation techniques used, repetition of food preparations and combinations, types of meat and offer of fruits and vegetables, as well as the 
characteristics of foods. Since the stage of menu planning is critical in the process of production of meals and will define their quality, the QEMP method can aid in the perception of nutritional balance and preparation methods aiming to make meals more attractive to students for a healthier consumption (6). School meal menus must be prepared by a nutritionist according to NSFP guidelines with the use of basic food, respecting nutritional needs, eating habits and local food culture (7). In this context, these menus may represent the possibility of contributing to a health-promoting contextualized food (8). According to Domene et al. (9), there are few studies that evaluate school menus under the nutritional aspect. Thus, this study was aimed at qualitatively analyzing menus planned and executed in a public school in the city of Rio de Janeiro (RJ).

\section{MATERIAL AND METHODS}

A cross-sectional quantitative study was carried out to evaluate the quality of menus planned and executed in a public School Food and Nutrition Unit (SFNU) of a city in the state of Rio de Janeiro - Brazil during the month of November 2012 from Monday through Friday, except holidays.

Before the data collection, it was found that the month of November would be a representative period of the school year, due to the absence of the events and activities at school that could compromise their planning and execution of menus.

Planned menus corresponded to the set of four weeks of menus prepared by the technical team of nutritionists responsible for the SFNU in the city under study for 46 municipal schools. After four weeks, planned menus are repeated in all SFNU. Executed menus were considered those prepared by food handlers in SFNU taking into consideration the planned menus for the period. Thus, the menus analyzed in this study can be considered representative of the remaining SFNU of the city.

Local schools work part-time and provide two daily meals (collation and lunch). Lunch menus planned and executed in a SFNU were characterized by the presence of starter, main course, garnish, accompaniment (rice/beans) and dessert, and were evaluated according to the QEMP method proposed by Proença et al. (6) with modifications. Through this method, the following variables of planned and executed menus with their possible responses were analyzed (table 1).

The responses to some variables for planned menus were obtained from informations with the technical team of nutritionists responsible for the planning of menus. In the case of executed menus, in loco observation of the pre-preparation, preparation and distribution of menus was performed, considering the lack of preparation technical files in SFNU, to obtain the responses.

Daily data obtained from the analysis of variables were grouped on a monthly evaluation and tabulated in relation to the total number of days of menus analyzed.

The results, tabulated in Microsoft Excel Software $2013 \circledast$, were expressed in percentage (\%) indicative of the nutritional and sensory quality and presented in graphs elaborated through the Microsoft Excel Software 2013®.

\section{RESULTS}

Overall, 15 planned menus and 15 menus used in lunches for the same period in the SFNU of the municipality of Rio de Janeiro - Brazil were analyzed. Figure 1 shows the results of the evaluation of the quality of preparation of menus planned and executed in the school by the QEMP method.
The planned and executed menus presented, respectively, a frequency of $20 \%$ and $26,7 \%$ of salads in relation to the total number of menus analyzed. Although planned menus had fruit in their composition, it was observed that $20 \%$ of menus did not have this food for dessert. Despite the absence of sweets in planned menus, the presence of $26,7 \%$ of sweets in executed menus by the offering of soft drinks sweetened with sugar was observed. In executed menus, color monotony was observed in $53,3 \%$ of preparations (figure 1). No food or preparations containing trans fats were observed (data not shown) and a small percentage of planned and executed menus presented foods source of sulfur $(13,3 \%$ and $6,7 \%$, respectively). In relation to garnishes, planned menus presented a percentage close to $50 \%$ of preparations based on hot vegetables and legumes (MA2), but in executed menus, this percentage decreased to $26,7 \%$. About $13,3 \%$ of planned menus showed absence of garnish (figure 1). Regarding meat preparation technique, $86,66 \%$ and $100 \%$ of planned and executed menus, respectively, showed stewed, soaked, cooked, plated or grilled meat preparations (MP). In executed menus, it was observed that almost all preparations were LFC $(93,30 \%)$ due to the use of LM and LP with or without added LS. In the case of planned menus, the classification of meat preparations such as LFC $(66,67 \%)$ was lower than that of executed menus $(93,30 \%)$ due to the greater presence of FM (20\%) and FP (13,33\%) in the preparation of main courses. There was no presence of garnishes and meat preparations with HFC offered concurrently with sweets in menus evaluated (data not shown).

\section{DISCUSSION}

The Brazilian NSFP incorporates several guidelines of the FNS policy which aims to ensure, in part, the fundamental right to food in the school environment through different strategies $(7,13)$. Accordingly, the provision of adequate and healthy food at school is established both as access expansion strategy as educational (12). Therefore, the school plays a key role in the formation of good eating habits by offering menus that can promote healthy eating habits (14).

Low frequency of meals containing vegetables in the form of salads or garnishes was observed. Importantly, the Food Guide for the Brazilian Population (FGBP) recommends 3 servings of fruits and 3 servings of vegetables per day as one of the attributes for a proper and healthy eating (15). The NSFP establishes a minimum of $200 \mathrm{~g} / \mathrm{student} /$ week of fruits and vegetables, but does not impose recommendation of consumption; therefore, it does not limit the offer to that amount. Thus, it is essential to establish strategies to expand the supply and consumption of these foods. One of them, proposed the NSFP, able to affect two major dimensions of FNS, namely, to promote healthy and adequate food and support sustainable development is the family agriculture $(16,3)$. The data found for the presence of salad are similar to those found by Menegazzo et al. (12), who observed a percentage of salads of $16.0 \%$ in the monthly menu of Children's Education Centers of Santa Catarina (SC) - Brazil. Bandeira et al. (17) analyzed the reports of School Feeding Councils of Brazilian cities and states on the implementation of NSFP and found a low percentage of schools that reported the meeting of per capita $200 \mathrm{~g}$ / student / week.

The absence in SFNU of an exclusive sink for washing and cleaning of vegetables can be a limiting factor for the inclusion of raw salads in the menus of Brazilian public schools. According to Oliveira et al. (18), SFNU often have characteristics of domestic kitchens, especially with regard to the physical 
structure. Regarding the presence of fruit on menus, the lowest percentage was $80 \%$ among executed menus. On the other hand, Menegazzo et al. (12) found a low supply of fruits in their study. Costa \& Mendonça (19) observed the presence of fruits in $100 \%$ of menus offered to preschool children in public and private kindergartens of the Federal District (DF) - Brazil. According to Robinson-O'Brien et al. (20), school meals should play a key role in encouraging and contributing to the daily intake of Fruits and Vegetables (FV) especially among children, which are considered a vulnerable group from the socioeconomic point of view. Unlike the findings of this study, Condon et al. (21), in a study conducted in 2005 with 699 grammar schools participating in the National Program of School Lunch of the United States, found a low supply of fruits and juices offered to American schoolchildren.
A positive fact found in our study was the increased presence of meat preparations with LFC. It is known that the excessive consumption of meat rich in fat has been implicated in increased risk factor for the development of Noncommunicable Chronic Diseases (NCD) and some types of cancer $(22,23)$. Menegazzo et al. (12) found $12 \%$ of color monotony in the menus for preschool children, similar to data found on planned menus of this work. Similarly, Costa \& Mendonça (19) found $13.3 \%$ of color monotony in the menus of a Brazilian public kindergarten. Increased color monotony of executed menus in our study may be related to unscheduled changes due, for example, to delays in the delivery of foods and / or adjustments made by the school management or team of cookers. It is known that color monotony has a direct relationship with the diversity of nutrients and acceptance of preparations (15).

\section{TABLE 1}

Variables and response options used in the analysis of menus planned and executed in a public school in the state of Rio de Janeiro by the QEMP method.

\begin{tabular}{|c|c|}
\hline Variables & Response options \\
\hline Salad. & $\begin{array}{l}\text { Yes: preparations based on raw or cooked vegetables (vegetables B) and/or leafy vegetables (ve- } \\
\text { getables A) served at refrigerator temperature; } \\
\text { No. }\end{array}$ \\
\hline Type of garnish. & $\begin{array}{l}\text { Meat Accompaniment } 1(\mathrm{MA} 1) \text { : preparations made from cereals, pasta, roots and tubers; } \\
\text { Meat Accompaniment } 2(\mathrm{MA} 2) \text { : preparations based on hot vegetables and legumes (vegetables } \\
\text { B) (10). }\end{array}$ \\
\hline Fat content of garnish. & $\begin{array}{l}\text { High Fat Content (HFC): fried preparations or added of greasy sauce; } \\
\text { Low Fat Content (LFC): cooked, soaked or stewed preparations with no addition of fat sauce (10). }\end{array}$ \\
\hline Type of meat. & $\begin{array}{l}\text { Fat Meats (FM): offal, pork, poultry with skin, chuck, dried meat and sausages; } \\
\text { Lean meats (LM): topside, silverside, knuckle, eye of round, skinless chicken and fish (10). }\end{array}$ \\
\hline Meat preparations. & $\begin{array}{l}\text { Lean (LP): Stewed, soaked, cooked, plated or grilled meat preparations; } \\
\text { Fat (FP): fried meat preparations or added of fat sauce (11). }\end{array}$ \\
\hline Meat sauces. & $\begin{array}{l}\text { Lean sauce (LS): those without addition of cheese or sour cream. } \\
\text { Fat sauce (FS): those with addition of cheese or sour cream (10); }\end{array}$ \\
\hline Meat preparation classification. & $\begin{array}{l}\text { This variable was evaluated based on responses obtained from the previous three variables related } \\
\text { to meat. } \\
\text { Low Fat Content (LFC): when they were composed of LM / LP and LM / LP / FS; } \\
\text { Intermediate Fat Content (IFC) when composed of GC / PM and FM / LP / LS; } \\
\text { High Fat Content (HFC) when composed of FM / FP, CM / PG, CM / PG / LS and LM / LP / FS. }\end{array}$ \\
\hline Presence of fruit. & Yes or no. \\
\hline Color monotony. & $\begin{array}{l}\text { Yes: when at least } 50 \% \text { of preparations showed similar colors according to Menegazzo et al. (12); } \\
\text { No. }\end{array}$ \\
\hline Presence of meal rich in sulfur. & $\begin{array}{l}\text { Yes: when two or more foods or preparations sources of sulfur, excluding beans, were present in } \\
\text { the same menu (12); } \\
\text { No. }\end{array}$ \\
\hline resence of sweets. & $\begin{array}{l}\text { Yes: when desserts or soft drinks made with table sugar were present; } \\
\text { No. }\end{array}$ \\
\hline
\end{tabular}

Presence of HFC garnish and sweet in the same lunch meal. No.

Presence of HFC meat preparation and sweet in the same lunch meal. Yes or no.

Presence of HFC garnish, HFC meat preparation and sweet in the same lunch meal.

Presence of HFC garnish and HFC meat preparation in the same lunch meal.

Presence of preparations containing Yes: for TFA identification in lunch preparations, the lists of food ingredients used in the preparation trans fatty acids (TFA).

Yes or no.

Yes or no.

Yes or no. of meals were analyzed and the following names were considered TFA: hydrogenated vegetable fat, hydrogenated fat, vegetable fat and partially hydrogenated fat; No. 
FIGURE 1.

Analysis of menus planned and executed in a public school in the state of Rio de Janeiro by the QEMP method.
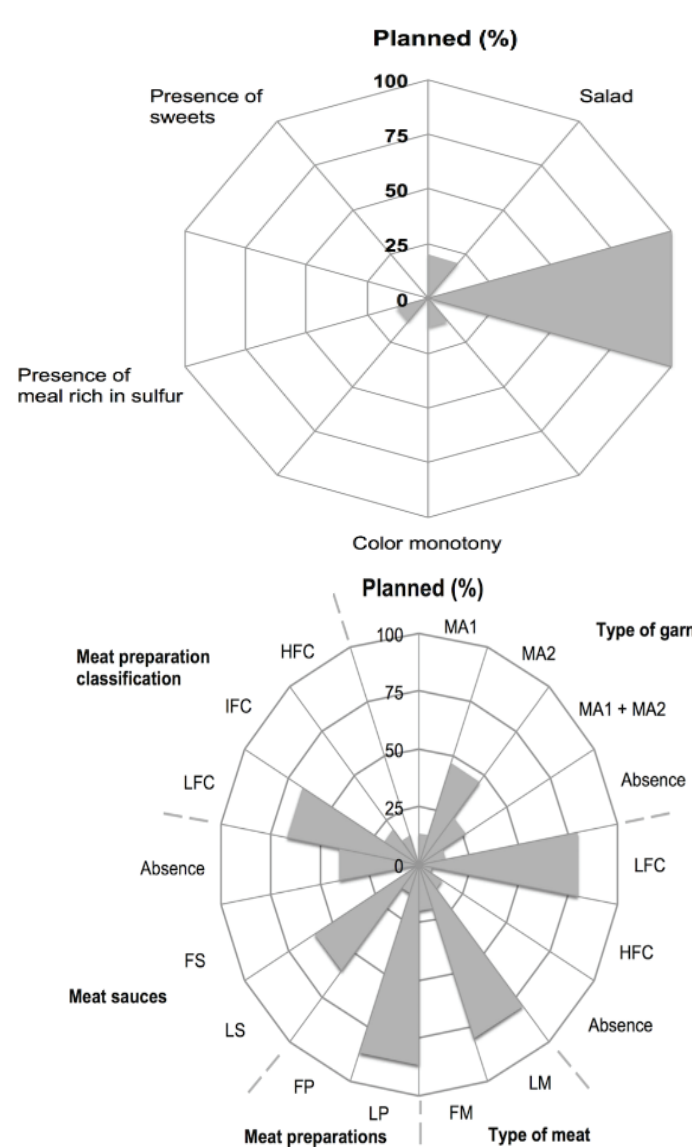

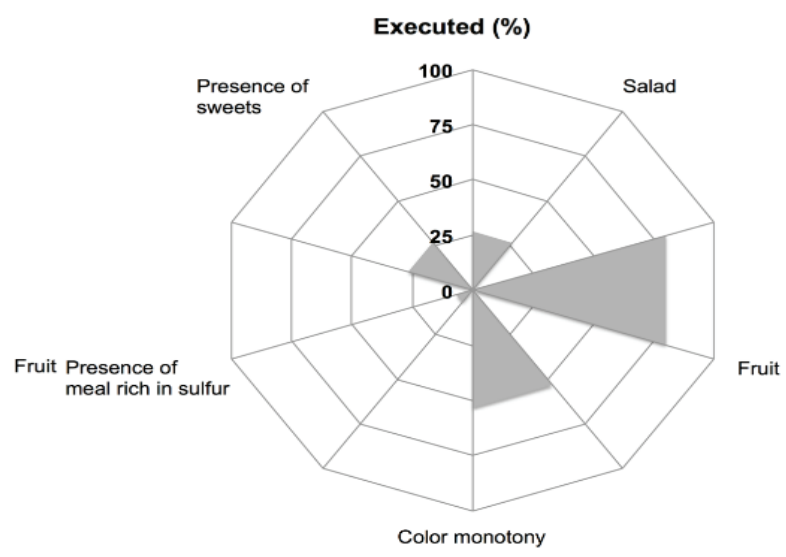

Executed (\%)

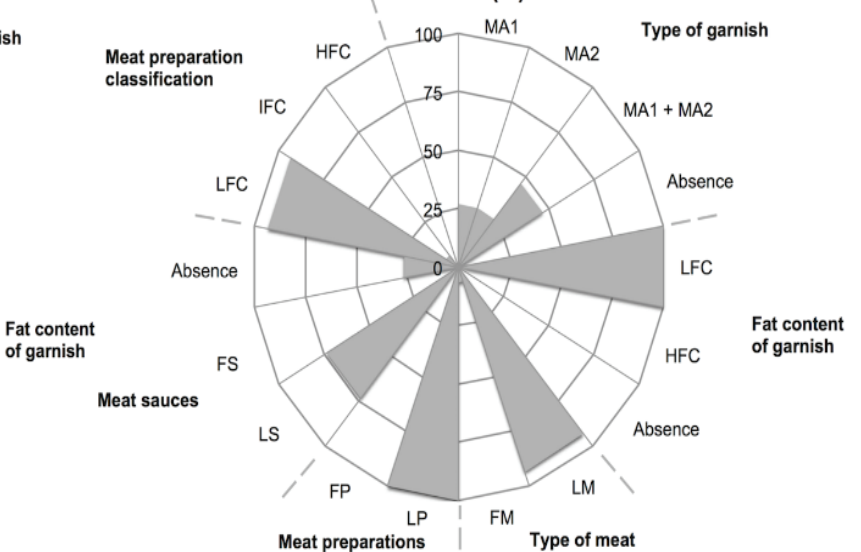

The low percentage of meals rich in sulfur in executed menus can be considered positive since the oversupply of sulfur can lead to gastric discomfort (9). As for sweets, although no sweets such as desserts had been offered, sweetened soft drinks were present in $26,7 \%$ of menus. However, this value was much lower than that found by Costa \& Mendonça (19), who verified the presence of sweets in $90 \%$ of menus offered in public daycare centers of DF - Brazil. In a study by Condon et al. (21), the offer of sweets was observed in $36 \%$ of menus of American elementary schools. Excess sweets may constitute a risk factor for the development of NCD, tooth decay and lack of intake of better nutritional quality food (24). In 2013, Longo-Silva et al. (25) assessed using the QEMP method menus of public childcare centers in São Paulo (Brazil) and showed insufficient supply of vegetables in almost every day associated with significant supply of sweets and foods with trans fat. The presence of sweets in over $25 \%$ menus associated with color monotony in over $50 \%$ of them suggests the need to review the acquisition of foodstuffs and increased supervision during the production of meals at SFNU. In other words, proper planning and control the delivery of materials, could minimize failures, delays or failures in delivery that end up by compromising the nutritional quality of menus. Problems related to purchases in public administration can also be a complicating factor for the execution of planned menus. Despite the existence of a team of nutritionists responsible for the management of school meals in the city studied, local schools do not have the daily presence of these professionals. In 2012, Paiva et al. (26) pointed to the importance of the presence of nutritionists in schools in order to control the quality of the food supply. According to Carvalho et al. (27), the nutritionist at NSFP in Brazil is responsible for a large number of schools, preventing the supervision and decision-making during the production process of meals in different schools. In addition, the Regional Council of Nutritionists - 4th Brazilian region indicated that menus executed at SFNU of the state of RJ did not correspond to planned menus (28). The absence of foods and preparations with TFA in the analyzed menus is a positive aspect in view of the role of these fats in the development of NCD and impaired the growth and development of children (29). These results are 
in accordance with the recommendation of the World Health Organization to eliminate TFA from the diet (30).

The main differences between planned and executed menus can be attributed to unscheduled changes in the delivery of foodstuff, municipal management problems at the NSFP and adjustments made by the school management team with a view to adjust menus to children's preferences or optimize the use of more perishable foodstuffs.

It is also important to emphasize that menu planning can be considered an educational strategy priority for schools. This instrument should ensure not only cover biological and nutritional needs, but also as a tool for food and nutrition education since eating habits are influenced by the school environment (31).

Therefore, the use of methods for evaluating the nutritional quality of school menus in Brazilian cities can assist in the construction of indicators to verify the contribution or not of the program to promote healthy eating habits at school. The QEMP method is a Brazilian instrument, and its comparison with international studies is difficult, which in general, analyze the menus from the quantitative nutritional point of view. However, it should be observed that this is a practical method that can be routinely used to control the quality of school menus.

\section{CONCLUSIONS}

The results of the evaluation of menus planned and executed in a SFNU in the city of RJ by the QEMP method can be considered a representation of its nutritional quality. However, for greater adequacy of menus, some adjustments should be implemented such as the increased supply of garnishes based on vegetables and legumes and salads in addition to the lower supply of sweets. Proper planning and control in the execution of school menus can contribute to promoting healthy eating habits among this population.

\section{RESUMEN}

El objetivo de este estudio fue realizar un análisis cualitativo de los menús planeados y ejecutados en una escuela pública del Estado de Río de Janeiro (Brasil). Durante 1 mes los menús escolares fueron evaluados de acuerdo al método de evaluación cualitativa de la preparación de menús utilizando variables relacionadas con los alimentos y preparaciones de comidas. Se evaluaron los datos en relación con el número total de días de los menús. Los menús planeados y ejecutados mostraron, respectivamente, $20 \%$ y $26,7 \%$ de presencia de ensalada, $100 \%$ y $80 \%$ de inclusión de frutas y $0 \%$ y $26,7 \%$ de presencia de dulces. En relación con las guarniciones, los menús planeados presentaron $50 \%$ de los preparados con verduras; sin embargo, en los menús ejecutados, este porcentaje fue $26,7 \%$. Las principales diferencias entre los menús fueron los cambios no programados que pueden contribuir negativamente a la calidad de las comidas escolares. Las reformulaciones en la planificación de menús y un mayor control en su aplicación se proponen como medidas para promover hábitos alimenticios saludables en el ámbito escolar.

Palabras clave: Programa de alimentación; análisis cualitativo; comida escolar; niño; planificación de menús.

\section{BIBLIOGRAPHY}

1. Brasil. Conselho Nacional de Segurança Alimentar e Nutricional. A Segurança Alimentar e Nutricional e o Direito Humano à Alimentação Adequada no Brasil. Indicadores e Monitoramento. Da Constituição de 1988 aos dias atuais. Available at: http:// www2.planalto.gov.br/ consea/biblioteca/publicacoes/a-seguranca-alimentar-enutricional-e-o-direito-humano-a-alimentacao-adequada-no-brasil

2. Cunha DT, Botelho RBA, Brito RR, Pineli LLO, Stedefeldt E. Métodos para aplicar las pruebas de aceptación para la alimentación escolar: validación de la tarjeta lúdica. Rev Chil Nutr 2013; 40(4): 357-63.

3. Brasil. Fundo Nacional de Desenvolvimento da Educação. Resolução $n^{\circ} 26$ de 17 de junho de 2013. Dispõe sobre o atendimento da alimentação escolar aos alunos da educação básica no âmbito do Programa Nacional de Alimentação Escolar - PNAE. Available at: https:// www.fnde.gov.br/fndelegis/action/UrlPublicasAction. php?acao=abrirAtoPublico\&sgl_tipo=RES\&num_ ato $=00000026 \&$ seq_ato $=000 \& v / r_{\text {an }}=2013 \& s g I_{-}$ orgao $=F N D E / M E C$

4. Brasil. Lei $n^{\circ} 11.947$, de 16 de junho de 2009. Dispõe sobre o atendimento da alimentação escolar e do Programa Dinheiro Direto na Escola aos alunos da educação básica. Available at: http:// www.planalto.gov.br/ ccivil_03/_ato2007-2010/2009/lei/l11947.htm

5. Triches RM. Schneider S. Reconstruindo o "elo perdido": a reconexão da produção e do consumo de alimentos através do Programa de Alimentação Escolar no município de Dois Irmãos (RS). Segur Aliment Nutr. 2010; 17(1): 1-15.

6. Proença, RPC. Sousa, AA. Veiros, MB. Hering B. Qualidade nutricional e sensorial na produção de refeições. UFSC, Florianópolis, 2005.

7. Brasil. Fundo Nacional de Desenvolvimento da Educação. Available at: http://www.fnde.gov.br/programas/ alimentacao-escolar/alimentacao-escolar-apresentacao 2013.

8. Yokota RTC, Vasconcelos TF, Pinheiro ARO, Schmitz BAS, Coitinho DC, Rodrigues MLCF.. Projeto "a escola promovendo hábitos alimentares saudáveis": comparação de duas estratégias de educação nutricional no Distrito Federal, Brasil. Rev Nutr. 2010; 23(1): 37-47.

9. Domene SMA, Pereira TC, Arrivillaga RK. Estimativa da disponibilidade de zinco em refeições com preparações padronizadas da alimentação escolar do município de Campinas. Rev Nutr. 2008; 21(2): 161-7.

10. Veiros MB, Martinelli SS. Avaliação qualitativa das preparações do cardápio escolar-AQPC escola. Nutr Pauta 2012; 20(114): 5-12.

11. Philippi ST, Cruz ATR, Colucci ACA. Pirâmide alimentar para crianças de 2 a 3 anos. Rev Nutr. 2003; 16(1): 5-19.

12. Menegazzo M, Fracalossi K, Fernandes AC, Medeiros NI. Avaliação qualitativa das preparações do cardápio de centros de educação infantil. Rev Nutr 2011; 24(2): 243-51.

13. Sidaner E, Balaban D, Burlandy L. The Brazilian school feeding programme: an example of an integrated programme in support of food and nutrition security. Public Health Nutr. 2012; 16(6): 989-94.

14. Mascarenhas JMO, Santos JC. Avaliação da composição nutricional dos cardápios e custos da alimentação escolar da rede municipal de Conceição do Jacuípe/BA. Sitientibus 2006; 35(1): 75-90.

15. Brasil. Guia alimentar para a população brasileira: promovendo a alimentação saudável. Brasília: Ministério da Saúde; 2006. Available at: http:// dtr2001.saude.gov. br/editora/produtos/livros/pdf/05_1109_M.pdf

16. Carvalho DG. Licitações sustentáveis, alimentação esco- 
lar e desenvolvimento Regional: uma discussão sobre o poder de compra governamental a favor da sustentabilidade. Planej Pol Públ 2009; 32: 115-48.

17. Bandeira LM, Chagas CMSC, Gubert MB. Tora N. Monteiro RA. Análise dos pareceres conclusivos dos Conselhos de Alimentação Escolar sobre a execução do Programa Nacional de Alimentação Escolar. Rev Nutr. 2013; 26(3): 343-51.

18. Oliveira MN, Brasil ALD, Taddei JAAC. Avaliação das condições higiênico-sanitárias das cozinhas de creches públicas e filantrópicas. Ciênc Saúde Coletiva 2008; 13(3): 1051-60.

19. Costa SEPO, Mendonça KAN. Avaliação qualitativa de cardápios oferecidos para pré-escolares de creches do Distrito Federal. Univ Ci Saúde 2012; 10(1): 33-40.

20. Robinson-O'Brien R, Burgess-Champoux $T$, Haines J, Hannan PJ, Neumark-Sztainer D. Associations between school meals offered through the national school lunch program and the school breakfast program and fruit and vegetable intake among ethnically diverse, low-income children. J Sch Healt.2010; 80(10): 487-92.

21. Condon EM, Crepinsek MK, Fox MK. School meals: types of foods offered to and consumed by children at lunch and breakfast. J Am Diet Assoc. 2009; 109(2): S67-S78.

22. Lima FEL, Menezes TN, Tavares MP, Szarfarc SC, Fisberg RM. Ácidos graxos e doenças cardiovasculares: uma revisão. Rev Nutr. 2000; 13(2): 73-80.

23. Brasil. Instituto Nacional de Câncer José Alencar Gomes da Silva (INCA). Políticas e ações para prevenção do câncer no Brasil: alimentação, nutrição e atividade física. INCA, Rio de Janeiro, 2012.

24. Souza Filho MDS, Carvalho GDF, Martins CC. Consumo de alimentos ricos em açúcar e cárie dentária em préescolares. Arq Odontol. 2010; 46(3): 152-159.

25. Longo-Silva G, Toloni $M$, Rodrigues $S$, Rocha A, Taddei JAAC. A qualitative evaluation of the menu and plate waste in public day care centers in São Paulo city, Brazil. Rev Nutr.2013; 26(2): 135-44.

26. Paiva PYU, Santos DAC, Santos LCC, Souza BSR, Cruz CLJTC. Spinelli MGN, et al. A importância do nutricionista na qualidade de refeições escolares: estudo comparativo de cardápios de escolas particulares de ensino infantil no município de São Paulo. Rev Univap. 2012; 18(32): 23-30.

27. Carvalho AT, Muniz VM, Gomes JF, Samico I. Programa de alimentação escolar no município de João Pessoa - PB, Brasil: as merendeiras em foco. Interface 2008; 12(27): 823-34.

28. Conselho Regional de Nutricionistas $-4^{a}$ Região RJ - ES [Internet]. Relatório sobre a qualidade da alimentação oferecida por unidades escolares estaduais no Estado do Rio de Janeiro. 2013. Available at: http://www.crn4. org.br/cms/upl/arqs/relatorio_crn-4_-_avaliacao_qualidade_alimen-tacao_escolar_-_estado_rj.pdf

29. Chiara VL, Silva $R$, Jorge $R$, Brasil AP. Ácidos graxos trans: doenças cardiovasculares e saúde materno-infantil. Rev Nutr. 2002; 15(3): 341-9.

30. World Health Organization (WHO). Global strategy on diet, physical activity and health [Internet]. Geneva: WHO; 2004. Available at: http:// www.who.int/dietphysicalactivity/strategy/eb11344/strategy_english_web.pdf

31. Cervato-Mancuso AM, Silva GM, Cárdenas AP. Grupo focal con nutricionistas que actúan en la alimentación escolar: el menú como elemento pedagógico. Rev Chil Nutr. 2013; 40(3): 250-5. 